\title{
KINERJA USAHA MIRO KECIL MENENGAH MAKANAN KABUPATEN CIANJUR BERBASIS KOMITMEN, KOMPETENSI DAN MOTIVASI USAHA
}

\section{BUSINESS PERFORMANCE OF MIDDLE SMALL MEDIUM FOOD CIANJUR DISTRICT BASED ON BUSINESS COMMITMENT, COMPETENCE AND MOTIVATION}

\author{
Dwi Gemina; Ahmad Ginanjar \\ Program Management Study Faculty of Economics, University of Djuada \\ Email: dwigemina@gmail.com; Aginanjar311@gmail.com
}

\begin{abstract}
This study aims to determine and identify the effect of commitment, competence and business motivation both simultaneously and partially on the performance of small and medium-sized micro-enterprises in Cianjur Regency. The questionnaire was distributed to 53 business people he took using the proportional random sampling technique. The method used in this study is descriptive verification. The results of the study show that the variables of commitment, competence and business motivation simultaneously and partially influence the performance of small-scale micro-food businesses in Cianjur Regency. The performance variance of small micro-enterprises can be explained by the variables of commitment, competence and business motivation of $71.4 \%$, while the remainder is $28.6 \%$ from other variables not examined.
\end{abstract}

Keywords: Commitment, Competence, Business Motivation, Performance, Small Micro Enterprises

\begin{abstract}
ABSTRAK
Penelitian ini bertujuan untuk mengetahui dan mengidentifikasi pengaruh komitmen, kompetensi dan motivasi usaha baik secara simultan maupun parsial terhadap kinerja usaha mikro kecil menegah makanan di Kabupaten Cianjur. Kuesioner didistribusikan kepada 53 orang pelaku usaha yang diambil dengan teknik proposional random sampling. Metode yang digunakan pada penelitian ini adalah deskriftif verifikatif. Hasil penelitian bahwa variabel komitmen, kompetensi dan motivasi usaha secara simultan maupun parsial berpengaruh terhadap kinerja Usaha mikro kecil menegah makanan Kabupaten Cianjur. Variansi kinerja usaha mikro kecil menegah dapat dijelaskan oleh variabel komitmen, kompetensi dan motivasi usaha sebesar 71,4 persen, sedangkan sisanya sebesar 28,6 persen dari variabel lain yang tidak diteliti.
\end{abstract}

Kata Kunci : Komitmen, Kompetensi, Motivasi Usaha, Kinerja, Usaha Mikro Kecil Menegah 


\section{PENDAHULUAN}

Usaha Mikro Kecil Menengah (UMKM) merupakan kelompok usaha yang dapat bertahan ketika krisis ekonomi terjadi di negeri ini pada tahun 1998 dan 2008. Peran UMKM dalam pembangunan perekonomian, terutama penyediaan tenaga kerja dan sumber penghasilan bagi kelompok masyarakat berpenghasilan rendah, dan tingkat kemampuan UMKM sangat ditentukan oleh dukungan pemerintah. Salah satu upaya yang dapat dilakukan oleh pemerintah baik pusat maupun daerah yaitu meningkatkan kualitas daya saing melalui pengembangan sektor usaha. Usaha Mikro Kecil Menengah makanan termasuk kedalam kelompok usaha yang cukup signifikan perkembangannya di Indonesia. Kabupaten Cianjur memiliki berbagai tempat wisata yang terkenal, diantaranya terdapat Kebun Raya Cibodas, Istana Kepresidenan, dan Kawasan Cianjur Selatan hal ini menjadikan UMKM Kabupaten Cianjur khususnya UMKM makanan sangat potensial untuk dikembangkan sebagai oleh-oleh khas Cianjur. Saat ini Kabupaten Cianjur telah dikenal makanan khas Cianjur berupa taucho, roti, kue-kue dan manisan buah.

$$
\text { UMKM merupakan harapan }
$$

pemerintah untuk mengatasi masalah ekonomi dan meningkatkan perekonomian masyarakat, karena telah teruji mampu bertahan dan mengatasi lemahnya perekonomian yang di akibatkan oleh inflasi dan faktor-faktor lainnya. Adapun pertumbuhan Pendapatan Asli Daerah Kabupaten Cianjur adalah sebagai berikut:

Tabel 1.Pertumbuhan Pendapatan Asli Daerah (PAD) Kabupaten Cianjur Tahun 2014-2016

\begin{tabular}{llll}
\hline & \multicolumn{2}{l}{$\begin{array}{l}\text { Realisai Pendapatan Asli Daerah (PAD) Kabupaten Cianjur } \\
\text { (Dalam Rupiah) }\end{array}$} & \\
\cline { 2 - 4 } & $\mathbf{2 0 1 4}$ & $\mathbf{2 0 1 5}$ & $\mathbf{2 0 1 6}$ \\
\hline PAD & $411,538.567,54$ & $454.627 .908,74$ & $424.737 .689,80$ \\
\hline
\end{tabular}

Sumber: Badan Pusat Statistik (BPS) Kabupaten Cianjur, 2018 (diolah)

Berdasarkan data pada Tabel.1 menunjukan bahwa UMKM pertumbuhan Pendapatan Asli Daerah (PAD). Kabupaten Cianjur berfluktuatif yang disebabkan oleh turunnya kinerja UMKM. Sehingga perlu diketahui dengan permasalahan yang dihadapi UMKM dengan tenaga kerja yang ada sudah optimal atau belum, dengan mengetahui kinerjanya. Menurut Gemina dkk (2017:122) kinerja adalah kemampuan kerja yang ditunjukan dengan hasil kerja.

Upaya untuk meningkatkan kinerja UMKM salah satunya yaitu komitmen. Dalam dunia usaha komitmen sangat diperlukan agar kinerja sesuai dengan yang diharapkan. Menurut Triatna (2016:120) menyatakan bahwa komitmen sebagai kadar kesetiaan seseorang terhadap organisasi atau perusahaannya (UMKM) yang dicirikan oleh keinginannya untuk tetap menjadi bagian dari organisasi, berbuat yang terbaik untuk organisasi, dan selalu menjaga nama baik organisasi. UMKM makanan dihadapkan beberapa masalah yang menyebabkan menurunnya kinerja UMKM makanan. Salah satunya disebabkan oleh kurangnya komitmen pelaku usaha dalam menjalankan usahanya yang dapat di lihat dari fluktuasi jumlah UMKM.

Tabel 2. Pertumbuhan UMKM Makanan Kabupaten Cianjur Tahun 2016-2018

\begin{tabular}{ccc}
\hline Tahun & Jumlah UMKM & Tenaga Kerja \\
\hline 2016 & 140 & 1.724 \\
2017 & 145 & 1.916 \\
2018 & 110 & 1.803 \\
Total & 395 & 5443 \\
Rata-rata & 132 & 1814 \\
\hline
\end{tabular}

Sumber: Dinas Koperasi dan UKM Kabupaten Cianjur, 2019 (diolah) 
Berdasarkan Tabel 2 menunjukan bahwa jumlah UMKM makanan yang terdaftar di Dinas Koperasi dan UKM Kabupaten Cianjur pada tahun 2016 berjumlah 140 unit dengan tenaga kerja sebanyak 1.724 orang meningkat menjadi 140 unit pada tahun 2017 dengan tenaga kerja sebanyak 1.916 orang. Sedangkan Pada tahun 2018 mengalami penurunan menjadi 110 unit dengan jumlah tenaga kerja 1.803 orang.

Selain komitmen faktor lain yang mempengaruhi kinerja usaha yaitu kompetensi. Menurut menurut Alma
(2016:271) bahwa kompetensi merupakan kemampuan yang dimiliki seseorang untuk menjalankan pekerjaannya yang dilandasi keterampilan dan pengetahuan serta didukung oleh sifat kerja yang dituntut oleh pekerjaan. UMKM makanan dihadapkan beberapa masalah dalam menjalankan kegiatan usahanya salah satunya yaitu kurangnya kompetensi pelaku usaha untuk memasarkan hasil usahanya Hal ini akan berdampak pada kinerja UMKM makanan. Adapun jenis-jenis pemasaran UMKM di Kabupaten Cianjur sebagai berikut:

Tabel 3. Jenis-Jenis Pemasaran UMKM Makanan di Kabupaten Cianjur Tahun 2018

\begin{tabular}{llll}
\hline No & Jenis Pemasaran & Jumlah UMKM & Persentase (\%) \\
\hline 1 & Konvensional & 60 & 54,55 \\
2 & Online & 5 & 4,54 \\
3 & Waralaba & 9 & 8,18 \\
4 & Pameran & 36 & 32,73 \\
\hline & Jumlah & $\mathbf{1 1 0}$ & $\mathbf{1 0 0}$ \\
\hline
\end{tabular}

Sumber: Dinas Koperasi dan UKM Kabupaten Cianjur, 2019 (diolah)

Berdasarkan Tabel 3 menunjukan bahwa jumlah UMKM makanan pada tahun 2018 yang melakukan pemasaran dengan cara konvensional atau di jual secara langsung berjumlah 60 unit atau sebesar $54,55 \%$, pemasaran dengan media online sebabyak 5 unit atau sebesar $4,54 \%$, kerja sama dengan pihak lain menggunakan sistem waralaba berjumah 9 unit atau sebesar $8,18 \%$ dan melakukan pemasaran dengan cara mengikuti pameran sebanyak 36 unit atau sebesar 32,72\%. Hal ini menunjukan kondisi UMKM makanan di Kabupaten Cianjur mengalami kesulitan dalam memasarkan hasil produknya karena masih di dominasi oleh pemasaran secara konvensional.
Kemudian faktor lain yang dapat mempengaruhi Kinerja UMKM yaitu Motivasi Usaha. Menurut Saiman (2014:25) motivasi usaha adalah suatu kerelaan untuk berusaha seoptimal mungkin dalam mencapai tujuan organisasi yang dipengaruhi oleh kemampuan usaha untuk memuaskan kebutuhan individu. Salah satu indikator motivasi usaha yaitu dalam menentukan besaran labanya. Sejumlah pelaku UMKM makanan mengalami omset menurun yang disebabkan oleh banyaknya produk UMKM yang tidak mampu memasuki pasar global. Hal ini menyebabkan omzet penjualan dan laba tidak bisa tinggi. Berikut jumlah omzet UMKM makanan Kabupaten Cianjur tahun 2016-2017:

Tabel 4. Jumlah Omzet UMKM Makanan Kabupaten Cianjur Tahun 2016-2018

\begin{tabular}{cccc}
\hline Tahun & Jumlah UMKM & $\begin{array}{c}\text { Omzet Per Tahun } \\
\text { (Dalam Rupiah) }\end{array}$ & $\begin{array}{c}\text { Persentase } \\
(\%)\end{array}$ \\
\hline 2016 & 140 & 7.682 .664 .000 & - \\
2017 & 145 & 11.408 .265 .000 & 32,65 \\
2018 & 110 & 10.159 .865 .000 & $(10,94)$ \\
\hline
\end{tabular}

Sumber: Dinas Koperasi dan UKM Kabupaten Cianjur, 2019 
Berdasarkan Tabel 4 jumlah omzet UMKM makanan di Kabupaten Cianjur pada tahun 2107 sebesar Rp11.108.265.000 dan pada tahun 2018 mengalami penurunan sebesar 10,96\% menjadi Rp10.159.865.000 Beberapa UMKM bahkan menutup aktivitas usahanya karena menurunnya omzet penjualan sebagai penyebab penutupan usahanya. Tujuannya adalah untuk menganalisis tanggapan pelaku usaha terhadap komitmen, kompetensi, motivasi dan kinerja UMKM makanan Kabupaten Cianjur, serta mengetahui pengaruh komitmen, kompetensi dan motivasi usaha terhadap kinerja UMKM secara simultan dan parsial.

\section{MATERI DAN METODE}

\section{Manajemen Sumber Daya Manusia}

Manajemen sumber daya manusia sebagai proses pengelolaan manusia, melalui rencana, rekrutmen, seleksi, pelatihan, pengembangan, pemberian kompensasi, karier, keselamatan dan kesehatan serta menajaga hubungan industrial sampai pemutusan hubungan kerja guna mencapai tujuan perusahaan dan peningkatan kesejahteraan stakeholder. Kasmir (2016:6).

\section{Komitmen}

Komitmen merupakan perwujudan dari kerelaan seseorang dalam bentuk pengikatan diri dengan diri sendiri (individu) atau dengan organisasi yang digambarkan oleh besarnya usaha (tenaga, waktu, dan pikiran) untuk mencapai tujuan pribadi dan visi bersama. Dengan adanya komitmen yang tinggi diharapkan mampu memberikan usaha terbaik dalam mencapai tujuan individu ataupun tujuan bersama. Bagia (2015:41). Adapun indikator komitmen menurut Meyer dan Allen dalam Bagia (2015:47) menyatakan bahwa dalam komponen komitmen terdapat tiga dimensi, yaitu sebagai berikut: 1) Komitmen afektif yaitu bagian dari komitmen yang lebih menekankan pada pentingnya kongruensi antara nilai dan tujuan pengusaha dengan nilai dan tujuan usahanya; 2) Komitmen kontinyu, bagian dari komitmen dimana pelaku usaha akan bertahan atau meninggalkan usahnya karena melihat adanya pertimbangan rasional dari segi untung dan ruginya; 3) Komitmen normatif, salah satu bagian dari komitmen dimana pelaku usaha bertahan pada usahanya karena ia merasakan adanya suatu kewajiban.

\section{Kompetensi}

$\begin{array}{rrr}\text { Kompetensi } & \text { merupakan } & \text { Suatu } \\ \text { kemapuan untuk melaksanakan atau }\end{array}$ melakukan suatu pekerjaan atau tugas yang dilandasi atas keterampilan dan pengetahuhan yang di dukung oleh sikap kerja. Adapun indikator kompetensi manajemen sumber daya manusia UMKM meliputi: 1) pengetahuan (knowladge); 2) keterampilan (skill) dan 3) sikap (attitude). (Wibowo, 2016:110).

\section{Motivasi Usaha}

Motivasi usaha merupakan suatu kerelaan untuk berusaha seoptimal mungkin dalam mencapai tujuan organisasi yang dipengaruhi oleh kemampuan usaha untuk memuaskan kebutuhan individu. Terdapat beberapa indikator motivasi usaha yang dapat di gunakan untuk mengetahui motivasi usaha seorang pelaku usaha dalam menjalankan usahanya menurut Saiman (2014:26) membagi kedalam 4 (empat) hal berikut; 1) laba; 2) kebebasan; 3) impian personal dan 4) kemandirian.

\section{Kinerja}

Kinerja menurut Andriany dan Rusli (2008:239) bahwa kesuksesan terlihat dari perkembangan usaha yang dilihat dari perkembangan modal, bahan baku, produksi, karyawan dan keuntungan sedangkan menurut suryana (2013:168) Kinerja merupakan modifikasi keinginan untuk memenuhi tujuan bisnis. Adapun indikator kinerja menurut Suryana adalah sebagai berikut: 1) Tingkat penjualan; 2) Penciptaan lapangan pekerjaan; 3) Tingkat stabilitas usaha: 4) Tingkat keuntungan; 5) Kontribusi terhadap pajak; 6) Pertumbuhan 
organisasi; 7) Penguasaan pasar; 8) Pendapatan untuk keluarga; 9) Biaya rendah; 10) Mempekerjakan karyawan Profesional; 11) Memiliki tugas terstruktur.

\section{Usaha Mikro Kecil Menengah (UMKM)}

Usaha mikro kecil menengah (UMKM) merupakan usaha yang mampu bertahan ketika krisis ekonomi terjadi di Indonesia. Usaha ini mampu menyerap tenaga kerja dan berkontribusi dalam mendistribusikan hasilhasil pembangunan dan menggunakan sumber daya lokal. Terdapat ciri khas dari UMKM, yaitu modal yang kecil, jumlah pekerja yang sedikit, risiko yang sedikit tinggi tetapi return tinggi, biasanya digerakkan dari rumah tangga, dan membawa kewirausahaan bagi pemiliknya (Isnaini, 2010:78).

\section{Pengembangan Hipotesis}

Komitmen merupakan kesediaan seseorang untuk tetap setia dan mau memberikan kinerja terbaiknya bagi usahanya. Triatna (2016:120) menyatakan bahwa komitmen sebagai kadar kesetiaan pelaku usaha terhadap usaha/perusahaannya yang dicirikan oleh keinginannya untuk tetap berbuat yang terbaik untuk usahanya. Kompetensi tidak hanya mengandung keterampilan, pengetahuan, dan kemampuan serta sikap, namun yang penting adalah penerapan dari keterampilan, pengetahuan, kemampuan dan sikap mereka sesuai standar kinerja yang ditetapkan (Enceng, 2008). Simanjuntak dan Calam (2012:3) menyatakan bahwa motivasi merupakan hal yang sangat penting dan harus dimulai oleh setiap orang dalam rangka meningkatkan kinerja usahanya, motivasi berasal dari bahasa latin movere yang berarti bergerak. Motivasi merupakan salah satu faktor penentu dalam pencapaian tujuan. Motivasi berhubungan dengan dorongan atau kekuatan yang berada dalam diri manusia. Menurut Indriati (2015:4) kinerja merupakan hasil interaksi antara komitmen motivasi, kompetensi dan peluang yang dapat berupa jumlah penjualan, jumlah produksi, tingkat kualitas, efisiensi biaya, profit dan sebagainya.

Penelitian terdahulu yang dilakukan oleh Muslim (2018) menunjukan bahwa secara simultan dan parsial kompetensi dan motivasi usaha berpengaruh positif dan signifikan terhadap kinerja UMKM Kerajinan Kota Bogor. Penelitian yang dilakukan oleh Sumantri dan Gemina (2015) bahwa secara simultan dan parsial kepribadian individual, self efficacy serta locus of control berpengaruh positif dan signifikan terhadap kinerja UMKM. Sedangkan faktor pendukung terhadap kinerja UMKM adalah faktor kepribadian individual, self efficacy dan locus of control.Fu'ad (2016) menunjukan bahwa secara simultan dan parsial kompensi dan motivasi kerja berpengaruh positif dan signifikan terhadap kinerja manajer koperasi di Kabupaten Jepara.Anggraini dkk (2016) bahwa secara simultan dan parsial karakteristik dan kompetensi wirausaha berpengaruh positif dan signifikan terhadap bisnis UMKM Pemuda Binaan Dispora Kabupaten Asahan.maka hipotesisnya adalah:

1. Komitmen berpengaruh positif dan signifikan terhadap kinerja UMKM makanan.

2. Kompetensi berpengaruhi positif dan signifikan terhadap kinerja UMKM makanan.

3. Motivasi usaha berpengaruh positif dan signifikanterhadap kinerja UMKM makanan.

4. Komitmen, kompetensi dan motivasi usaha berpengaruh positif dan signifikan terhadap kinerja UMKM makanan

Gambar tersebut memperlihatkan kerangka pemikiran. 


\section{Permasalahan Penelitian}

Menurunnya kinerja UMKM terlihat mdalui Menurunya jumlah UMKM makanan di Kabupaten Cianjur turun pada tahun 2018 turun sebesar $31,8 \%$. Pemasar an masih di lakukan dengan cara konvensional sebesar $54,55 \%$ Omzet UMKM menurun sebesar $10,96 \%$

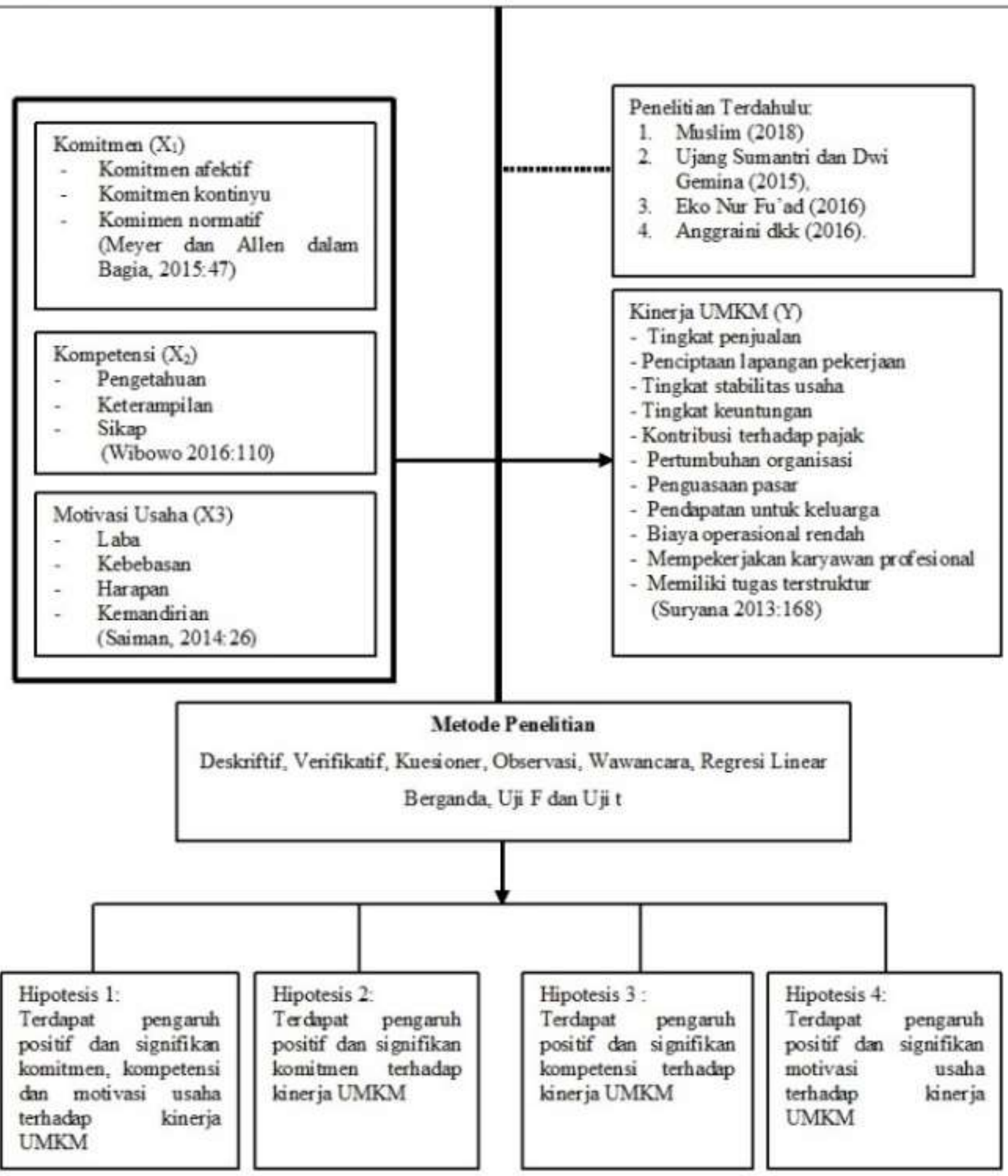

\section{Gambar 1. Kerangka Pemikiran}




\section{Metode Penelitian}

Objek pada penelitian ini adalah pelaku usaha pada Usaha Mikro Kecil dan Menengah (UMKM) di Kabupaten Cianjur. Adapun lokasi penelitian yang dipilih dalam penelitian ini adalah UMKM makanan yang terdaftar di Dinas Usaha kecil Menengah Kabupaten Cianjur sebanyak 110
unit.Teknik pengambilan sampel yang digunakan dalam penelitian ini adalah teknik purposive random sampling didapatkan hasil sample sebanyak 53 orang. Penentuan jumlah sampel dan porsi pada jenis usaha makanan didasarkan pada perhitungan berikut.

Tabel 5. Sampel Pelaku Usaha Proposional Random Sampling

\begin{tabular}{clcc}
\hline No & \multicolumn{1}{c}{ Jenis Makanan } & Perhitungan & Jumlah Sampel \\
& & $18 / 110 \times 53$ & 8 \\
1 & Manisan & $36 / 110 \times 53$ & 17 \\
2 & Roti & $17 / 110 \times 53$ & 8 \\
3 & Kue basah & $12 / 110 \times 53$ & 7 \\
4 & Kue kering & $27 / 110 \times 53$ & 13 \\
5 & Olahan pangan lainnya & & $\mathbf{5 3}$ \\
\hline
\end{tabular}

Sumber: Dinas Koperasi dan UKM Kabupaten Cianjur 2018 (diolah)

Penelitian memakai metode deskriptif juga verifikatif diperolehpemilahan dataDinas Koperasi dan UMKM Penelitian ini menggunakan data primer didapat penyebaran kuesioner. Data lain dipakai data sekunder dari olah data primer itu sendiri. Pengujian data menggunakan uji validitas, reliabilitas, uji asumsi klasik yaituuji normalitas, uji multikolonieritas, dan uji heterokedastisitas. Setelah semua instrument diuji, selanjutnya dilakukan regresi linear berganda, korelasi berganda, koefisien determinasi, pengujian hipotesis secara simultan (Uji F) dan terakhir adalah pengujian secara parsial (Uji t).

Operasionalisasi variabel yaitu suatu hubungan antara konsep abstrak dengan dunia empiris melalui observasi dan menggunakan berbagai instrumen pengukuran yang ada sehingga diperoleh informasi tentang hal tersebut, kemudian ditarik kesimpulannya Morissan (2016:75)

Tabel 6. Operasionalisasi Variabel

\begin{tabular}{|c|c|c|c|}
\hline Variabel & Konsep Variabel & Indikator & Skala Ukur \\
\hline $\begin{array}{l}\text { Komitmen } \\
\text { (X1) }\end{array}$ & $\begin{array}{l}\text { Kadar kesetiaan seseorang terhadap } \\
\text { organisasi atau usahaannya yang } \\
\text { dicirikan oleh keinginannya untuk tetap } \\
\text { menjadi bagian dari organisasi, berbuat } \\
\text { yang terbaik untuk organisasi, dan } \\
\text { selalu menjaga nama baik organisasi. } \\
\text { (Meyer dan Allen dalam Bagia, } \\
\text { 2015:47) }\end{array}$ & $\begin{array}{l}\text { 1. Komitmen afektif } \\
\text { 2. Komitmen kontinyu } \\
\text { 3. Komitmen normatif }\end{array}$ & $\begin{array}{l}\text { Ordinal } \\
\text { Likert } \\
(1-5)\end{array}$ \\
\hline $\begin{array}{l}\text { Kompetensi } \\
\text { (X2) }\end{array}$ & $\begin{array}{l}\text { Suatu kemapuan untuk melaksanakan } \\
\text { atau melakukan suatu pekerjaan atau } \\
\text { tugas yang dilandasi atas keterampilan } \\
\text { dan pengetahuhan yang di dukung oleh } \\
\text { sikap kerja. (Wibowo, 2016:110) }\end{array}$ & $\begin{array}{ll}\text { 1. } & \text { Pengetahuan } \\
\text { 2. Keterampilan } \\
\text { 3. Sikap }\end{array}$ & $\begin{array}{l}\text { Ordinal } \\
\text { Likert } \\
(1-5)\end{array}$ \\
\hline $\begin{array}{c}\text { Motivasi } \\
\text { Usaha (X3) }\end{array}$ & $\begin{array}{l}\text { suatu kerelaan untuk berusaha seoptimal } \\
\text { mungkin dalam mencapai tujuan } \\
\text { organisasi yang dipengaruhi oleh } \\
\text { kemampuan usaha untuk memuaskan } \\
\text { kebutuhan individu. Saiman }(2014: 26)\end{array}$ & $\begin{array}{ll}\text { 1. } & \text { Laba } \\
\text { 2. } & \text { Kebebasan } \\
3 & \text { Impian Personal } \\
4 & \text { Kemandirian }\end{array}$ & $\begin{array}{l}\text { Ordinal } \\
\text { Likert } \\
(1-5)\end{array}$ \\
\hline
\end{tabular}




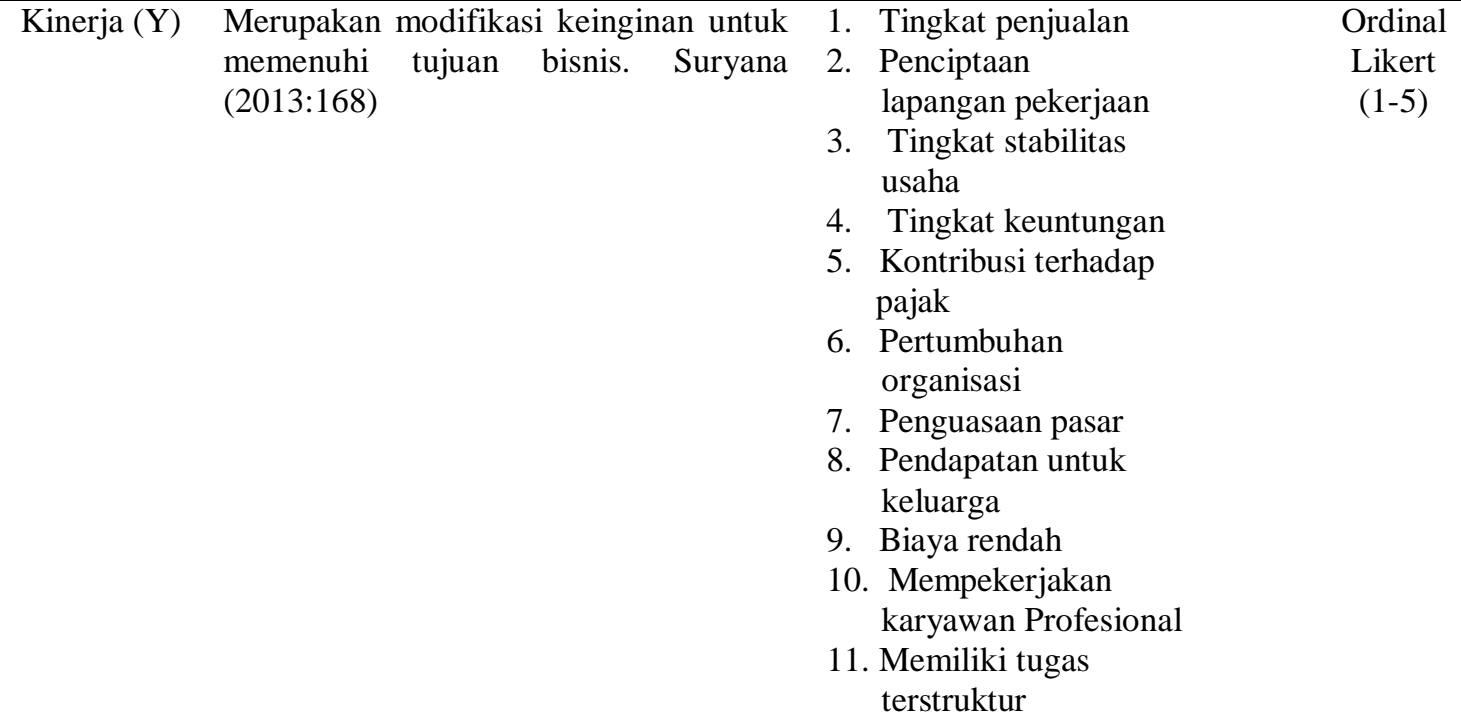

7. Penguasaan pasar

8. Pendapatan untuk keluarga

9. Biaya rendah

10. Mempekerjakan karyawan Profesional

11. Memiliki tugas terstruktur

\section{HASIL PENELITIAN}

\section{Karakteristik Rekapitulasi Pelaku Usaha}

Berdasarkan data diperoleh bahwa mayoritas pelaku usaha adalah laki laki dengan jumlah 39 orang atau sebesar $73,6 \%$ dan mayoritas berstatus sudah menikah dengan presentasi sebesar $94,3 \%$ atau berjumlah 50 orang. Adapun tingkat pendidikan terakhir para pelaku usaha yaitu SMA/Sederajat sebanyak 24 orang dengan presentasi sebesar 45,28 \%. Lama usaha yang telah dijalani mayoritas lebih dari 10 tahun dengan presentasi sebesar 75,48 atau sebanyak 40 orang. Sedangkan pendapatan pertahun yang di peroleh yaitu sebesar Rp600 juta - Rp2,5 miliar yaitu berjumlah 20 orang dengan presentasi sebesar $37,73 \%$. Jumlah aset yang dimiliki mayoritas pelaku usaha yaitu sebesar Rp100 juta- Rp500 juta dengan presentasi sebesar 32,08\%. Sedangkan jumlah tenaga kerja 5-19 orang atau sebanyak 23 orang dengan presentasi sebesar $43,40 \%$.

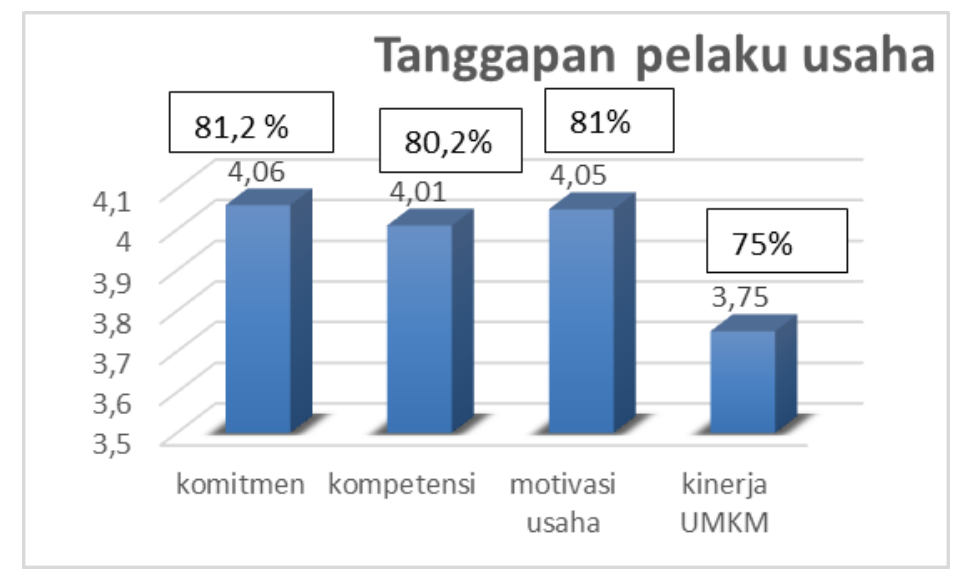

Gambar 2. Rekapitulasi Hasil Kuesioner

Pada Gambar 5 tanggapanpelaku usaha terhadap komitmenmemiliki rata-rata penilaian sebesar 4,06atau 81,2 \% dengan kategori tinggi Hal ini menunjukan bahwa komitmen merupakan salah satu hal penting dalam mencapai kinerja UMKM yang tinggi. Rata-rata penilaian pelaku usaha terhadap kompetensi sebesar 4,01atau 80,2\% dengan kategori baik. Hal ini menunjukan bahwa kompetensi merupakan salah satu hal penting dalam mencapai kinerja UMKM yang tinggiRata-rata penilaian pelaku usaha terhadap motivasi usaha sebesar 4,05atau 81 persen dengan kategori tinggi Hal ini 
menunjukan bahwa motivasi usaha merupakan salah satu hal penting dalam mencapai kinerja UMKM yang tinggi. Ratarata penilaian pelakuu usaha terhadap kinrja UMKM sebesar 3,75atau 75 persen dengan kategori tinggi Hal ini menunjukan bahwa secara umum kinerja UMKM makanan Kabupaten Cianjurtermasuk dalam kategori tinggi.

\section{Uji Validitas dan Reliabilitas Instrumen Penelitian}

Uji validitas dilakukan dengan tujuan mengukur pernyataan atau pertanyaan dalam kuesioner. Menurut Sugiyono (2013:166) menyatakan bahwa uji validitas berguna untuk mengetahui apakah ada pertanyaanpertanyaan pada kuesioner yang harus dibuang/diganti karena dianggap tidak relevan Data dinyatakan valid jika pernyataan atau pertanyaan itu bisa ungkapsesuatu. Berdasarkan pengujian instrument kepada tiga puluh (30) pelaku usaha menunjukkan bahwa uji validitas terkait variabel Komitmen Kompetensi dan motivasi usaha, dan variabel terikat yakni kinerja UMKMbisa dikatakan valid, dapat dilanjutkan ke pengujian reliabilitas.
Uji reliabilitas ialah alat pengukur kuesioner semua indikator variabel, instrumen yang reliabel adalah instrumen yang bila digunakan beberapa kali untuk mengukur objek yang sama akan menghasilkan data yang lebih sama Sugiyono (2016:121) Berdasarkan pengujian instrument penelitian kepada tiga puluh (30) Pelaku usaha menunjukkan bahwa dari komitmen, kompetensi dan motivasi usaha dan kinerja UMKM diperoleh hasil jika seluruh item reliabel karena memiliki Cronbach Alpha> 0,6.

\section{Uji Asumsi Klasik}

Hasil uji yaitu a) Uji normalitas bahwa data dinyatakan terdistribusi normal; b) Uji multikolonieritas tidak multikoloni antara variabel bebasnya; c) Uji heterokedastisitas tidak heterokedastisitas dari semua model regresi sehingga semua model regresi dapat dilanjutkan ke uji regresi linear berganda.

\section{Hasil Pengolahan Data}

Analisis data memakaisoftware SPSS22.0 diperoleh hasil persamaan berikut:

\section{Tabel 7. Hasil Estimasi Persamaan Regresi}

\begin{tabular}{lcccc}
\hline Variabel & B & t hitung & Sig t & Beta \\
\hline Variabel & & & & \\
Constant & -19.611 & -1.513 & .137 & .315 \\
Komitmen & 1.270 & 3.549 & .001 & .452 \\
Kompetensi & 1.709 & 4.030 & .000 & .234 \\
Motivasi usaha & .728 & 2.164 & .035 & \\
Kinerja & & & & \\
t table & 1,684 & F hitung & 44.314 & \\
R & .855 & F table & 3,18 & \\
R square & .731 & Sig F & $.000^{\mathrm{b}}$ & \\
\hline
\end{tabular}

Sumber: Data Diolah, 2019

Berdasarkan ringkasan hasil perhitungan menggunakan regresi berganda dipakaibisa menjelaskan 73,1 persen dari variabel dependen sedangkan sisanya 26,9 persen pengaruhi oleh lain diantaranya yang disampaikan Wahyudianti (2017) yang menyatakan hasil penelitiannya menunjukan bahwa faktor yang mempengaruhi kinerja UMKM salah satunya yaitu aspek keuangan.
Sedangkan nilai $\mathrm{R}$ sebesar 0,855 yang artinya hubungan antara variabel komitmen, kompetensi dan motivasi usaha sangat kuat. Kepercayaan 95 persen variabel TQM secara simultan pengaruh kinerja UMKM. Secara parsial Komitmen, kompetensi dan motivasi usaha secara parsial mempengaruhi positif signifikan. 


\section{PEMBAHASAN}

\section{Pengaruh Secara Simultan Komitmen, Kompetensi dan Motivasi Usaha terhadap \\ Kinerja UMKM Makanan Kabupaten Cianjur}

Hasil pengujian diperoleh Fhitung sebesar 44,314 dan nilai Ftabel untuk $\alpha$ $=0,05$ dengan derajat kebebasan $\mathrm{V} 1=3-1=2$ dan V2=53-3-1=49 sebesar 3,18 dimana bisa dilihat bahwa Fhitung lebih besar dari Ftabel $(44,312$ >3,18) maka dapat disimpulakn bahwa Ho ditolak dan Ha diterima, artinya dengan tingkat kepercayaan $95 \%$ variabel independen komitmen, kompetensi dan motivasi usaha terhadap kinerja UMKM makanan Kabupaten Cianjur. Megantoro (2015) dalam penelitiannya menyatakan bahwa kinerja seseorang dipengaruhi oleh dua faktor yaitu Faktor kemampuan, terdiri dari pengetahuan dan keterampilan serta Faktor motivasi, terdiri dari kondisi sosial, kebutuhan individu dan kondisi fisik. Sunyoto (2012) menyatakan bahwa motivasi adalah suatu perangsang keinginan (want) daya penggerak kemauan bekerja seseorang, setiap motif mempunyai tujuan tertentu yang ingin dicapai. Fu'ad (2016) dalam penelitianya mengatakan bahwa terdapat pengaruh antara kompetensi dan motivasi terhadap kinerja.

\section{Pengaruh Komimen Terhadap Kinerja UMKM}

dapat dilihat bahwa thitung pada variabel Komitmen sebesar 3,549 dan nilai tabel untuk $\alpha=0,05$ dengan derajat kebebasan 53-3-1=49 sebesar 1,684 berarti thitung $>$ tabel $(3,549$ $>1,684)$ dengan nilai signifikansi $0,01<0,05$ maka Ha diterima dan Ho ditolak artinya secara parsial faktor komitmen berpengaruh positif dan signifikan terhadap kinerja Hal ini didukung oleh penelitan Sutrisni (2014) dan Bahri (2017) menyatakan bahwa secara parsial komitmen berpengaruh terhadap kinerja UMKM.

\section{Pengaruh KompetensiTerhadap Kinerja UMKM}

Hasil pengujian diperoleh nilai thitung pada variabel kompetensi bahwa thitung sebesar 4,030 dan nilai t tabel untuk $\alpha=0,05$ dengan derajat kebebasan 53-3-1=49 sebesar 1.684 berarti thitung $>$ tabel $(4,030>1,684)$ dengan nilai signifikansi $0,00<0,05$ maka Ha diterima dan Ho ditolak artinya secara parsial faktor kompetensi berpengaruh positif dan signifikan terhadap kinerja UMKM makanan Kabupaten Cianjur. Hal ini didukung oleh hasil penelitian Marliana (2011) dan Yuliana (2017) menyatakan bahwa secara parsial kompetensi berpengaruh terhadap kinerja UMKM.

\section{Pengaruh Motivasi Usaha Terhadap Kinerja UMKM}

Hasil pengujian thitung pada variabel motivasi usaha sebesar 2,164 dan nilai tabel untuk $\alpha=0,05$ dengan derajat kebebasan 53$3-1=49$ sebesar 1,684 berarti thitung $>$ ttabel $(2,164>1,684)$ dengan nilai signifikansi $0,033<0,05$ maka Ha diterima dan Ho ditolak artinya secara parsial faktor motivasi usaha berpengaruh positif dan signifikan terhadap kinerja UMKM makanan Kabupaten Cianjur. Hal ini didukung oleh penelitian Murty (2012) dan Trihudiatmanto (2017) menyatakan bahwa secara parsial motivasi usaha berpengaruh terhadap kinerja UMKM.

\section{KESIMPULAN DAN IMPLIKASI}

Kesimpulan penelitian ini adalah :

a. Berdasarkan tanggapan para pelaku usaha terhadap masing-masing indikator pada variabael komitmen, kompetensi dan motivasi usaha terhadap kinerja UMKM: a) Rata-rata tanggapan pelaku usaha terhadap variabel komitmen termasuk kategori baik, elaku usaha terhadap variabel kompetensi termasuk kategori baik tanggapan pelaku usaha terhadap variabel motivasi usaha 
termasuk kategori baik, tanggapan pelaku usaha terhadap variabel kinerja UMKM termasuk kategori tinggi.

b. Berdasarkan hasil pengujian secara simultan komitmen, kompetensi dan motivasi usaha (bersama-sama) berpengaruh positif dan signifikan terhadap kinerja UMKM makanan Kabupaten Cianjur.

c. Berdasarkan hasil pengujian secara parsial Komitmen,Kompetensidan Motivasi usaha berpengaruh positif dan signifikan terhadap kinerja UMKM makanan Kabupaten Cianjur.

Implikasi dalam penelitian ini adalah sebagai berikut:

a. Keyakinan pelaku UMKM, terhadap usaha yang dijalankan akan berhasil serta kewajiban untuk mengembangkan usaha perlu ditingkatkan, dengan senantiasa selalu berfikir optimis serta menanamkan keyakinan dalam diri bahawa pelaku usaha mampu mengembangkan usahanya dan percaya pada produk yang di hasilkan mampu bersaing di pasaran

b. Keterampilan dalam mengelola dan membuat laporan keuangan pelaku UMKM makanan Kabupaten Cianjur perlu ditingkatkan agar setiap pemasukan dan pengeluaran dapat terkontrol dengan baik. Dibutuhkan peran serta pemerintah melalui Dinas Koperasi dan UMKM Kabupaten Cianjur dalam

memberikan penyuluhan dan pelatihan terhadap para pelaku UMKM makanan Kabupaten Cianjur;

c. Pelaku usaha perlu melakukan evaluasi rutin terkait pencapaian laba agar sesuai dengan yang diharapkan dan menentukan target laba agar usaha yang dijalankan dapat meningkat dan berkembang

d. Bagi yang hendak akan melakukan penelitian lanjutan manajemen sumber daya manusia di UMKM makanan Kabupaten Cianjur hendaknya memperdalam kajian mengenai faktorfaktor kinerja seperti aspek keuangan, teknis produksi, aspek sosial dan kebijakan pemerintah sehingga dapat menjadikan penelitian ini sebagai data tambahan

\section{UCAPAN TERIMA KASIH}

Ucapan terima kasih kepada Pelaku Usaha Mikro Kecil Menengah Makanan Kabupaten Cianjur.

\section{DAFTAR PUSTAKA}

Agus Tri Basuki, Immamudin Yuliadi. 2015. Electronic Data Processing (SPSS15 dan EVIEW 7). Yogyakarta. Danisa Media:

Alma Buchari. 2016. Kewirausahaan untuk Mahasiswa dan Umum. Alfabeta: Bandung

Ardian, I.D.K.R. Brahmayanti dan Subaedi. 2010. Kompetensi SDM UKM dan Pengaruhnya Terhadap Kinerja UKM di Surabaya. Surabaya: Fakultas Ekonomi Universitas 17 Agustus. Vol. 12, No.1 Juli, Hal 4255

Arikunto, Suharsimi.2011. Prosedur Penelitian: Suatu Pendekatan Praktek. Jakarta. Rineka Cipta.

Badan Pusat Statistik . 2017. Potensi Ekonomi Jawa Barat.

Badan Pusat Statistik Kabupaten Cianjur. 2018. Cianjur dalam Angka.

Bagia. 2015. Perilaku Organisasi.

Yogyakarta. Graha Ilmu:

Dinas Koperasi dan Usaha Mikro Kecil Menengah Kabupaten Cianjur. 2018. Data UMKM Kabupaten Cianjur. Echdar, Saban. 2017. Metode Penelitian Manajemen dan Bisnis. Bogor.Penerbit Galia Indonesia.

Edison, Emron. Anwar, Yohny dan Komariah, Imas. 2017. Manajemen Sumber Daya Manusia. Bandung. Alfabeta.

Enceng, Liestyono dan Purwaningdyah. 2008. Meningkatkan Kompetensi Aparatur Pemerintahan Daerah dalam Mewujudkan Good Governance. Jurnal Kebijakan dan Manajemen. Vol 2 Hal 12-25 
Fuad, Eko Nur. 2016. Pengaruh Kompetensi dan Motivasi Kerja Terhadap Kinerja Manjer Koperasi di Kabupaten Jepara. Fakultas Ekonomi dan Bisnis UNISNU Jepara. ISSN 2407-9189. Hal 56-72

Fred Luthans .2006. Perilaku Organisasi edisi sepuluh.Yogyakarta.PT Andi.

Gemina, Dwi. Endang, Silaningsih dan Yuningsih, Erni. 2016. Pengaruh Motivasi Usaha Terhadap Keberhasilan Usaha Sebagai Variabel Mediasi Pada Industri Kecil Menengah Makanan Ringan Priangan Timur-Indonesia. Jurnal Manajemen Teknologi. Vol. 15, No.3 ISSN: 1693-5241, Hal 297-323.

Hasibuan, Malayu SP, 2010. Manajemen Sumber Daya Manusia Edisi Revisi. Jakarta.PT. Bumiaksara.

Hendar, 2010. Manajemen Perusahaan Koperasi. Jakarta. Erlangga.

Indriati, Ashri. 2015. Strategi Peningkatan Kualitas Sumber Daya Manusia Untuk Meningkatkan Kinerja Usaha Kecil Menengah. Skripsi. Institut Pertanian Bogor. Https://ipb.ac.id di Akses Pada 9 November 2018 Pukul 10:30.
Jonathan, Sarwono. 2006. Metode Penelitian Kuantitatif dan Kualitatif. Yogyakarta.Graha Ilmu.

Kasmir, 2016. Manajemen Sumber Daya Manusia Teori dan Praktek. Jakarta.PT. Rajagrafindo Persada.

Minuzu,musran. 2010 Pengaruh FaktorFaktor Eksternal dan Internal terhadap Kinerja UMK Kabupaten Sulawesi selatan. Jurnal Manajemen dan kewirausahaan, Vol V No.3, Hal 115-123.

Megantoro, Dwi. 2015. Pengaruh keterampilan, pengalaman, kemampuan sumber Daya Manusia terhadap kinerja Usaha Kecil Menengah (Studi Kasus di panjang rejo, Srihardono Pundong Bantul Yogyakarta)

Simanjuntak dan Calam 2013 Pengaruh Kepemimpinan Transformasi dan Motivasi Kerja Terhadap Kinerja Karyawan PT PLN (Persero) Cabang Binjai Wilayah Sumatra Utara. Jurnal SAINTIKOM. Vol 11. No 2

Sunyoto. 2012 Manajemen Sumber Daya Manusia. CAPS. Yogyakarta. 